\title{
Entrevista da família para a obtenção de órgãos e tecidos para transplante
}

\author{
Family Interview for the Procurement of Organs and Tissues for Transplantation
}

\author{
Sidney Júlio de Faria e Sousa ${ }^{\left({ }^{()}\right.}$Stella Barretto ${ }^{(2)}$
}

\section{INTRODUÇÃO}

Sempre que se fala em captação de órgãos, a primeira idéia é a da promoção de uma grande campanha, seguida da distribuição de cartões de doação. Esta estratégia geralmente falha pois cartão de doação não é sinônimo de tecido doado. Não há dúvidas de que as campanhas aumentem a disposição da população para doar órgãos. Porém, na hora da morte, as famílias não se lembram de comunicar o óbito à equipe de captação de órgãos, tornando o cartão pouco eficaz. Além disso, o eventual aumento das doações tende a desaparecer com o término da campanha. A figura 1 mostra os resultados efêmeros de uma extensa campanha de doação de olhos no ano de 1991, realizada por nós, em Ribeirão Preto.

O segredo do sucesso na captação de órgãos está na busca da doação, que implica na procura ativa da família para a formalização do pedido ${ }^{1}$. É o contrário da captação passiva, na qual a equipe de captação fica aguardando a doação espontânea dos familiares. A busca também pode ser direta ou indireta. Entende-se por busca direta, a estratégia de captação em que a própria equipe pede a doação diretamente à família, sem intermediários. A busca é indireta quando transfere o encargo a terceiros, como médicos, enfermeiras, religiosos, agentes funerários e outros. Entretanto, como o pedido é sempre feito num momento desfavorável, é preciso que se adotem condutas de aproximação pessoal que criem condições propícias à doação, sem ferir sentimentos. Essas condutas são agrupadas sob o nome de técnicas de entrevista familiar. Uma vez que o assunto é pouco explorado na literatura, faremos uma revisão, esperando com isso, contribuir para o aumento da captação de órgãos para transplantes.

Este trabalho partiu do pressuposto de que a entrevista é feita em ambiente hospitalar e de que a solicitação da doação esteja a cargo de um Banco de Olhos. No entanto, a maior parte das informações aqui expostas, continua sendo válida para outros ambientes e outras áreas de captação, desde que convenientemente adaptadas às particularidades de cada caso.

\footnotetext{
(1) Professor Associado da Faculdade de Medicina de Ribeirão Preto, Universidade de São Paulo.

(2) Banco de Olhos do Hospital das Clínicas da FMRP-USP.

Endereco para correspondência: Sidney J. de Faria e Sousa - Hospital das Clínicas de Ribeirão Preto - Depto. Oftalmologia - Campus Universitário da USP. Ribeirão Preto (SP) CEP 14049-900.
}

Na técnica de entrevista familiar, vários pontos são levados em conta ${ }^{2}$. Os itens subseqüentes descrevem esses pontos.

\section{Quem deve pedir a doação?}

Uma das características principais da pessoa que pede a doação é que não tenha pressa. Por isso, nem o médico nem a enfermeira são as pessoas mais adequadas para a tarefa, já que tendem a trabalhar com pouca folga de tempo. Eles também não costumam ter tempo para adquirir treinamento específico no assunto. $\mathrm{O}$ ideal é que esse trabalho seja realizado por técnicos especializados. Na falta deles, pode-se empregar assistentes sociais, religiosos, estudantes de medicina ou voluntários de variadas profissões com alguma familiaridade com a área de saúde.

Não é aconselhável que membros da equipe médica de transplante façam o pedido de doação. Isto pode gerar a impressão de que o corpo do ente querido esteja sendo alvo de cobiça médica.

\section{Quando fazer a abordagem?}

Em termos de tempo, a regra básica é que o pedido da doação seja feito somente após a certeza da família ter sido avisada da morte. Um dos mais lamentáveis incidentes é o pedido ocorrer antes do aviso do óbito. Não basta a informa-

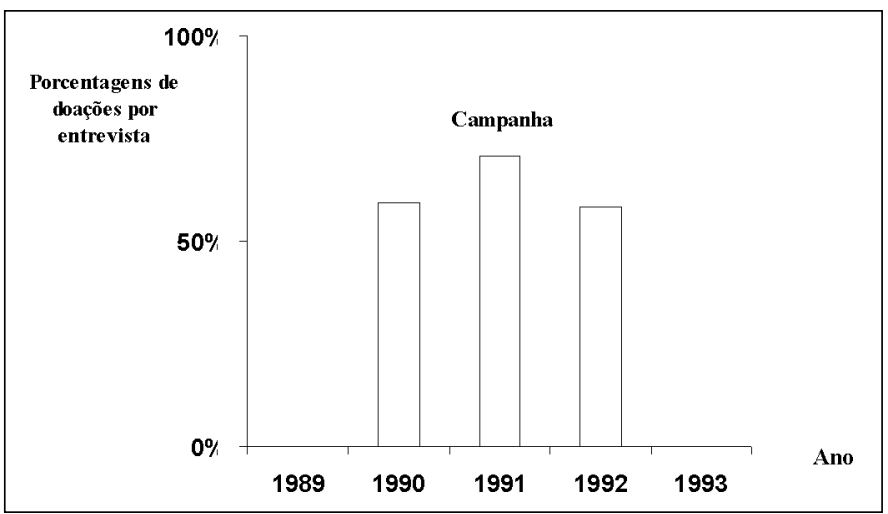

Fig. 1 - Efeitos da campanha no rádio e na televisão sobre porcentagem de doações por entrevista familiar, no ano de 1991, na cidade de Ribeirão Preto, promovida pelo Banco de Olhos do Hospital das Clínicas da FMRP-USP. 
ção genérica, de que a família já tenha sido avisada. É preciso saber o nome do parente contatado. Deve-se sempre considerar a possibilidade de que um ente próximo tenha sido temporariamente poupado pela família.

Outro caso propenso a incidentes é o da morte cerebral. Normalmente, os familiares não entendem o problema e, por isso, devem ser esclarecidos pela equipe médica. Se isso não ocorrer, eles certamente ficarão muito ofendidos com um pedido de doação. É imperioso, pois, que o pedido seja feito somente depois do pronunciamento oficial da morte cerebral e após a ciência de que o assunto já tenha sido convenientemente discutido com a família do morto.

Finalmente, nenhuma abordagem deve ser feita sem o conhecimento das circunstâncias da morte. É uma questão de respeito e até mesmo de estratégia de aproximação familiar.

\section{Com quem falar?}

Uma situação muito intimidante para quem faz a entrevista é quando se depara com um grande número de familiares agrupados num canto do hospital. Algumas das pessoas estão em pranto, desoladas com a perda do ente querido. Outras, inconformadas com as circunstâncias da morte. Outras, ainda, descontentes com tudo, tentando achar um culpado pela situação. Completando o quadro, crianças correm de lá para cá, irritando todos. O exemplo é extremo, mas exprime bem a necessidade do uso de métodos de aproximação, que evitem incidentes desagradáveis.

Para lidar com essa situação, o primeiro passo é identificar o parente mais próximo que mostre condições de diálogo. Em vez da esposa, às vezes é melhor escolher o filho adulto mais velho ou o mais calmo. Isole essa pessoa do grupo, conduzindo-a para um local privado. Se ela pedir pela presença de outras, aceite, mas guardando o princípio de falar com o mínimo possível de familiares de uma só vez. Tente falar apenas com pessoas com poder de decisão. Exclua as crianças pois elas só tendem a tumultuar o ambiente de conversação.

\section{Onde conversar?}

O local de conversa deve ser sossegado. De preferência, numa sala isolada. Se possível, ao redor de uma mesa para manter a solenidade do encontro. Em nosso país isso nem sempre é viável, obrigando a adaptações criativas ditadas pelas condições locais. Entretanto, existem três regras que não devem ser violadas:

1. Evite conversar com a família em corredores, a menos que seja isolado. Encontros nesses locais, além de quebrar a cerimônia do pedido, favorecem a aglomeração de outros familiares não desejados e até de transeuntes curiosos.

2. Evite as capelas. Muitos familiares, na hora da morte, estão revoltados com Deus e a abordagem num ambiente divino favorece a exacerbação desse sentimento. Outras pessoas podem sentir-se pressionadas pelo ambiente e ficar ultrajadas com a atitude do entrevistador.

3. Nunca peça a doação ao lado do leito de morte. Isto tende a ser profundamente desrespeitoso aos familiares. O pedido, nesse ambiente, acaba funcionando como uma proposta de mutilação.

\section{Maneira de falar}

A maneira de falar influencia todo o relacionamento humano e obviamente qualquer pedido. Com respeito ao pedido de doação, é preciso compreender que a pessoa que acaba de perder um ente querido não reage como o habitual. Ela está deprimida e, nessa condição, o raciocínio é lento. Ruídos e agitação tornam-se exacerbados e muito desagradáveis. Para entrar em sintonia com elas, é preciso usar voz baixa, entonação calma, linguagem simples e postura relaxada.

As respostas favoráveis também parecem estar relacionadas com a identificação social entre o entrevistador e a família. Aparentemente, um entrevistador de hábitos e conversa humilde tende a ter mais sucesso com as famílias humildes. Outro, de hábitos e conversa mais elaborados, tende a ter mais sucesso com as famílias mais instruídas. É óbvio que não é possível escolher um entrevistador para cada tipo de família. Entretanto, essa informação é importante na hora da contratação do entrevistador.

\section{Etapas da entrevista}

A técnica da entrevista da família inclui quatro etapas: preparação do clima, introdução do assunto, sondagem de dúvidas e resposta à decisão familiar. Cada uma dessas etapas será analisada nos itens adiante.

\section{Preparação do clima}

A preparação do clima para o pedido de doação é, de todas as etapas, a mais dependente da criatividade do entrevistador. Em princípio, ele deve apresentar-se à família dizendo o nome, identificando sua autoridade, expressando os sentimentos pela morte e oferecendo ajuda. Nessa fase, não se fala em doação.

A peça fundamental de aproximação a ser explorada é a ajuda às necessidades imediatas da família que perdeu o ente querido. Em hospitais universitários, por exemplo, este assunto tende a ser flagrantemente ignorado. Entre os familiares, são comuns as seguintes perguntas: Vai haver autópsia? Quando será liberado o corpo? Como eu escolho a funerária? Onde posso fazer chamadas interurbanas? Existe uma cantina aberta a esta hora? Essas dúvidas muitas vezes se transformam num verdadeiro martírio para a família. A pessoa, que as soluciona com boa vontade, tem grande chance de obter aceitação e atenção da mesma.

Assumindo que a família já esteja ciente do óbito, uma abordagem pode começar da seguinte maneira: - Boa tarde. Meu nome é Antônio. Eu trabalho neste hospital. Meus sentimentos pela morte do senhor Adolfo. Gostaria de saber se existe alguma coisa em que eu possa ajudar? A gente sabe que nessas horas tudo é tão difícil... Repare que o entrevistador não mencionou sua função, que implicaria a citação do Banco de Olhos, que por sua vez, poderia despertar algum sentimento defensivo. Em vez disso, ele expressou sua autoridade de membro da instituição.

\section{Introdução do assunto}

Uma vez conquistada a simpatia da família, o entrevistador escolhe um membro da mesma e convida-o a conversar em 
local apropriado. Apresenta o serviço de transplantes de córnea. Explica o que é a córnea em linguagem bem simples. Fala sobre a importância da doação. Menciona que o tempo de retirada do tecido é rápido e que isso não atrapalha o enterro. Assegura que o processo de retirada do órgão não provoca desfiguração do cadáver e pede a doação.

Um exemplo da conversação desta etapa seria: - Sr. Júlio, este hospital oferece a oportunidade às familias de doarem as córneas dos seus entes queridos, para a recuperação da visão de pessoas cegas. A córnea é uma capinha transparente que existe na frente do olho, igual ao vidro de um relógio. Existem muitas crianças que não freqüentam escola, muitos pais que não conseguem mais sustentar a familia, aguardando uma córnea para enxergar. A retirada da córnea é rápida e não atrapalha o enterro. Também não desfigura a pessoa, não fica feio, porque a reconstrução é perfeita. Todo gasto na retirada da córnea é coberto pelo hospital. A gente pede apenas para que o familiar assine uma autorização. O que o senhor acha disso?

É importante perceber que o pedido é feito de modo evasivo. A questão não foi posta de modo a exigir um "Sim" ou "Não". Se a pergunta fosse: - O senhor gostaria de doar as córneas do Sr. Adolfo?, a resposta poderia ser um vigoroso $\mathrm{NÃO}$, e o entrevistador ficaria sem argumentos.

\section{Sondagem de dúvidas}

A pergunta anterior dá oportunidade ao familiar de expressar o que realmente sente, desvendando dúvidas, mitos e desinformações. Verble e Worth ${ }^{2}$ sustentam que as principais objeções relativas à doação de tecidos se enquadram numa das seguintes categorias: objeções técnicas, objeções práticas e objeções místicas.

As objeções técnicas incluem o medo da remoção do órgão em vida, do apressamento da morte, preocupação com o desperdício do tecido e desconfiança sobre a venda de órgãos. As objeções práticas incluem a preocupação com o atraso no funeral, com a aparência do cadáver, medo da reprovação dos demais familiares e parentes e insegurança de decidir sobre assunto desconhecido. As objeções místicas relacionam-se com o medo de que o ente querido sinta dor à remoção do órgão, medo da mutilação, necessidade do órgão no além e motivos religiosos. Quanto melhor for o diagnóstico da causa da insegurança do entrevistado, melhores serão as chances de resolvê-las e obter a anuência à doação.

O entrevistador deve manter a conversa, sondando dúvidas por meio de perguntas amistosas até que o familiar chegue a uma decisão consciente. Por exemplo, diante de uma negativa insegura, em vez de perguntar: - Por que o senhor não quer doar?, o melhor seria: - Eu compreendo que o senhor ache que a doação não é a melhor decisão para a sua família. Muito justo. No entanto, o Senhor poderia falar um pouco mais sobre suas dúvidas quanto à doação? Isto pode ajudar a pessoa a rever sua decisão fazendo aflorar uma série de sentimentos mesmo que não relacionados com a doação, como por exemplo, um descontentamento velado com o atendimento hospitalar.

\section{Resposta à decisão}

A maioria das famílias concorda com a doação. Nossa sociedade é favorável a ela. Uma vez obtido o consentimento verbal, o entrevistador solicita a assinatura do formulário de doação. Embora nossa legislação não estabeleça ordem de prioridade, o ideal é que seja feita pelo parente mais próximo possível.

Nos casos em que a família não concorda com doação, o entrevistador deve aceitar o veredicto com naturalidade, apoiando a decisão. Jamais deve tomar qualquer atitude que gere desconforto ou arrependimento. Entretanto, se sentir que a negativa é feita sem convicção, deve voltar a investigar as dúvidas que estão gerando a insegurança. A idéia não é conseguir um "Sim “, mas uma resposta consciente. Não é raro que famílias que rejeitaram a doação venham posteriormente ter sensação de culpa pela decisão ${ }^{3}$.

Uma vez terminada a sessão, o entrevistador agradece a atenção, externa novamente seus sentimentos, deixa o número do telefone do Banco de Olhos e reencaminha o familiar ao local de origem.

\section{Entrevista pelo telefone}

Um dos gargalos às entrevistas hospitalares, particularmente nos hospitais regionais, é a dificuldade de encontrar os familiares do falecido. Como grande parte dos pacientes são de outras cidades, muitos parentes não são encontrados na hora do óbito. Nos dez anos de existência do Banco, nunca conseguimos entrevistar mais do que trinta por cento das famílias das pessoas falecidas em nosso hospital. Neste caso, a entrevista pode ser feita por telefone. Entretanto ela tem dois aspectos negativos: a impessoalidade e a falta de valor legal.

A impessoalidade da conversa telefônica é negativa por motivos óbvios. A falta de legalidade da doação verbal faz com que a entrevista deva ser complementada por visita domiciliar, para a assinatura do termo de consentimento. O problema é que a vitalidade efêmera do tecido doado limita fortemente o tempo disponível para essa atividade.

Não é exagero reiterar que a abordagem só deva acontecer após a certeza de que a pessoa contatada já esteja ciente do óbito. Em caso de anuência à doação, é preciso anotar o nome do entrevistado, o grau de parentesco, a data e hora da entrevista. No final, o entrevistador fornece seu nome e telefone para eventuais contatos.

\section{Benefícios da doação}

Quando se fala em doação de órgãos, é natural que se pense nos benefícios de quem as recebe. Entretanto, o que é esquecido, ou talvez desconhecido, é o benefício que ela traz à família da pessoa falecida. Familiares entrevistados, meses após o óbito, revelam que a doação funciona como um instrumento de consolo. Para alguns, ela é uma forma de gerar algo significativo de uma situação tão sem sentido como a morte. Para outros, ela propicia um prolongamento da vida em outro corpo. Para um terceiro grupo, representa um ato de boa vontade que ajuda a aproximação do ente querido de Deus. A doação torna-se então uma oportunidade para a família intervir favoravelmente nos destinos espirituais do parente morto.

À medida que o ato de doação vai ganhando força na 
comunidade, há uma tendência das pessoas considerarem-no um direito; um direito de exercício de religiosidade e de solidariedade. Elas passam a ficar desapontadas quando, diante da morte de um familiar, não são informadas da possibilidade de doações de órgãos. Consideram que, por negligência hospitalar, perderam a chance de exercer um ato aprovado por Deus e pela sociedade. Por outro lado, o entrevistador que lhes abriu o caminho para a doação é lembrado com respeito e carinho.

Com base nessa observação, vários Estados Americanos adotaram uma lei que transfere aos hospitais a obrigação de divulgarem o programa de doação de órgãos da região a que pertencem. Isto facilitou muito o contato dos Bancos de Olhos com os familiares, gerando um grande número de doações.

\section{Considerações finais}

A entrevista familiar, quando realizada de modo planejado, melhora não só o número de órgãos captados, como também contribui para a aceleração do processo de recuperação emocional do luto. A técnica por si só já favorece os resultados. Entretanto, para estes que sejam expressivos, é necessária a criação de um esquema intra-hospitalar no qual a equipe de captação seja avisada imediatamente de cada morte. Uma possibilidade é solicitar ao Serviço de Controle de Óbitos que, assim que o óbito seja comunicado à família, ele também o seja ao plantonista da equipe. A excelência porém se consegue somente com perseverança e profissionalismo. Para isso, é preciso investir na formação de técnicos especializados e considerar o Banco de Olhos (ou Banco de Órgãos), uma instituição com pessoal, infra-estrutura e orçamento e não um mero método de armazenagem de tecidos, operado por um médico benemérito que atua nas horas vagas.

\section{REFERÊNCIAS BIBLIOGRÁFICAS}

1. Requard JJ. Procurement of donor tissue. Manual of the American Association of Eyebank, pp. VI -1 - VI -14.

2. Verble MS; Worth JK. Procurement. Abstract of the Indiana Lions Eye Bank Course, June 1989.

3. Verble MS; Worth JK. Family counseling. In: Corneal Surgery: Theory, Technique and Tissue. Brightbill, F.S. ed., St. Louis, Mosby, $2^{\text {nd }}$. Ed., 1995, pp. 694-9. 